\title{
PERSONAL SALES SUCCESS FACTORS IN A WEALTHY AUTOMOTIVE MARKET ENVIRONMENT
}

\author{
Michael Stros \\ University of Applied Sciences and Arts of Southern Switzerland (SUPSI) \\ David Říha \\ University of Economics, Prague, Czech Republic \\ Elena Říhová \\ Skoda Auto University, Prague, Czech Republic \\ Lynn L.K. Lim \\ University of Applied Sciences and Arts of Southern Switzerland (FHNW)
}

\begin{abstract}
This study aimed to determine the success factors in personal sales in a wealthy market environment. For this purpose, a quasi-experimental design was formulated and the Swiss automotive market was selected. This market has some peculiarities in comparison to other markets, such as generally wealthy customers who demand fuel-efficient cars with significant horse power in the higher price range. Videos of personal sales conversations were produced and shown to the study participants for evaluation. The sales took place in the automotive sector, but the results can be transferred to other sectors. The theoretical concept of personal sales is introduced, sales theories, techniques and strategies are discussed. The different types of communication are introduced and explained. As a result, a factor analysis is conducted in order to interpret the results. The paper provides then conclusions by discussing and construing the results. Theoretical and managerial contributions and possible limitations are derived.
\end{abstract}

Keywords: Personal sales, Sales factors, Sales Techniques, Sales strategies, Market environment.

DOI: http://dx.doi.org/10.15549/jeecar.v6i1.270

\section{INTRODUCTION}

An unpredictable market environment, increasing competitive pressure, and everincreasing demands on the satisfaction of customer requirements can be identified as challenges for sales. Consequently, salespeople are an important pillar in sales success. Their knowledge about their market, products, and consumers have a major impact on the sales process. Furthermore, according to Pufahl
(2015), along with their knowledge, their attitude, ability, and empathy during the personal sales conversation can also be among the most relevant factors for sales success. As a result, personal interaction will influence the customer's purchase decision. Consequently, based on Homburg et al. (2012), the aim of the study is to determine the relevant factors with a positive impact on consumers during the sales conversation, leading to a sales decision. This study focuses on Switzerland's car selling 
business, using video material produced at an automotive dealership in the United States enabling to generalized the findings to other business markets and to compare cultural environments in further research (see also Říha, Heinze \& Stros, 2017; Stros, Říha \& MösleinTröppner, 2018; Stros, Heinze \& Říha, 2017).

The Swiss automotive market has some peculiarities with regard to other markets, which are of interest in research. According to Weber (2017), Swiss consumers value fuel efficiency and horsepower when buying a car, while they prefer light cars over heavy ones, with an increasing importance given to fuel efficiency. Furthermore, low-price sensitivity is present. This means that price is not the only decisive factor, but other sales-related criteria are of significance as well. A successful sales outcome is influenced by the salesperson's behaviour. In personal sales, different sales techniques and sales styles are established; however, the actual sales communication is conducted via verbal and non-verbal communication patterns.

\section{THEORETICAL FRAMEWORK}

Sales talk takes place between the salesperson and the potential buyer. The goal is to obtain the buyer's interest, to convince the buyer of the product, and to end the sales talk with a positive outcome (Springer, Fachmedien \& Wiesbaden, 2013). Hereby, sales talk is a relevant component within the overall sales process. Personal sales talk can be, depending on the industry and on the requirement of a product explanation, a central instrument in communication and sales, and therefore significant during the sales phase (Foscht et al., 2015). In general, the literature often proposes standardized sales procedures. Due to the standardization of sales processes and questions, the conversation's planning is facilitated. This controlled procedure can increase the salesperson's authenticity and persuasive power. Thus, s/he can concentrate better on the single reactions of his/her conversation partner and react in an appropriate way (Wage, 1991).

Sales talk is typically divided into three phases: (1) conversational "opening" phase, (2) "reasoning" phase and (3) "completion" phase. During the first phase, the "opening" phase, the customer is not sure whether $s /$ he is going to purchase the specific product. At this stage, the salesperson mainly presents the product or service by providing an overview of the whole offer. As soon as the product of interest to the customer has been detected, the salesperson supports the buyer in his/her search for information. In general, a pleasant atmosphere between the salesperson and the potential buyer should be ensured (Fischer, 1982). During the second part of a sales talk, the "reasoning" phase, the customer evaluates the product options. While there is existing information and related processing, individual arguments are being contrasted with each other and questioned. In the literature, this is called the beginning-end effect. This effect describes the customer's concentration during information intake, as the buyer receives most information at the beginning and at the end of the reasoning phase. If the customer expresses critical comments or concerns, the salesperson can be sure that the customer is thinking about the product. In the best case, the strongest arguments are mentioned at the beginning of the reasoning phase (Weis, 1994). Finally, during the third stage, the "completion" phase of the sales talk, the salesperson might have to deal with the customer's decision-making risk. If this risk occurs, it needs to be addressed by the salesperson (Fischer, 1982). The customer might show his/her indecisiveness regarding a purchase decision by asking for the price, delivery times and guarantee conditions as well as display non-verbal signals, such as changing position, taking a deep breath or reaching for the sales object (Weinberg, 1986).

A uniform structure for a sales pitch was proposed by St. Elmo Lewis (1903), who introduced the AIDA formula. The abbreviation AIDA stands for "attention", "interest", "desire" and "action". This formula provides a guideline for the individual phases of a conversation between a salesperson and a potential customer. "Attention" typifies the customer's attention, which is triggered by the salesperson and, in particular, the promoted product. "Interest" describes the phase in which the customer's interest in a specific product or service is awakened. "Desire" describes the customer's desire to purchase the product or service. In the last stage, the customer decides to make the purchase - this phase is known as "action" (Wage, 1991, p.13). In summary, it can be concluded that the AIDA formula is a feasible approach in personal sales and applicable to any sales situation, such as offensive or defensive 
customer involvement in sales talk. We should add that actual product marketing is an additional factor influencing sales success (Springer Fachmedien Wiesbaden, 2013). The theoretical concept of the AIDA formula is based on the elaboration likelihood model (ELM) of persuasion (Petty et al., 2004), which is a dualprocess theory describing changes in attitude. The ELM was developed by Richard E. Petty and John Cacioppo in 1980 (Kruglanski et al., 2012) and explains different ways of processing stimuli and their outcomes in terms of attitude change.

Regarding salesperson behaviour, Kirchgeorg and Wübbenhorst (2017, p.56) divide "purchasing behaviour" into two areas of relevant purchase characteristics: (1) the transmission of goods or service to a different economic entity and (2) the emergence of a financial liability. Furthermore, Kirchgeorg and Wübbenhorst (2017) suggest that "purchasing behaviour" is influenced by the following five core factors:

1. Choice amongst different brands

2. Diffusion of various behaviour patterns

3. Choice of shopping location

4. Type of buying person

5. Quantity and quality of the purchased goods

Furthermore, it is regarded as essential to distinguish between the different processes of purchasing behaviour that begin when individuals or groups purchase products or services, in order to develop appropriate sales strategies (Solomon et al., 2003). In addition, the buyer's product requirement might change during the sales process. As a result, the buyer could suddenly ask for a different product or service and express his/her actual desire (Solomon et al., 2003). As already highlighted, several factors play a role during a personal sales conversation. On the one hand, the buyer (customer) can influence the conversation, while, on the other hand, the salesperson can leave different impressions through his/her behaviour, both non-verbal and verbal. Through emotions, knowledge, gestures and facial expressions, s/he conveys relevant information to the buyer and provokes certain reactions (Solomon et al., 2003). Sigmund Freud (1938) described the ideal condition of the inner equilibrium in his work. He differentiated between body-related (body language, behavioural), emotional (feeling), and rational characteristics (cognition), which, if balanced, lead to an ideal emotional and mental state ("easiness"). The encounter with a person who is in the emotional state of being "uneasy" results in an inner uneasiness in the other person (see also Bauer, 2005) and therefore an imbalance in both people. An authentic appearance needs a state of balance. This is of significance as the success of the sales conversation itself is largely determined by the salesperson's authenticity (see also Bauer, 2005).

The salesperson's behaviour includes only those activities that are of importance for the sale, and support or confirm the company goals in any form. In addition to the advice and service given to the customer, his/her duties include responsibilities such as receiving new goods, article surveillance, presentation or visual merchandising, collecting, cleaning and caring for the sales area, and being involved in exchanges of or complaints about products. These activities vary from one company to another (Schuckel, 1999). This is in support of Churchill et al.'s (1985) statement: "what salespeople do are the tasks on which they expend effort while working“. It can be concluded that the salesperson's task is to win the customer's trust. The salesperson can exercise his/her influence over various behavioural patterns, such as different sales techniques and styles. The salesperson's "authenticity" is of central relevance.

In terms of non-verbal and verbal communication, personal interaction uses different channels for communication. Sales talk does not only contain "verbal" components, such as speaking, but also "non-verbal" components, such as body language. Besides linguistic signs, the speaker sends various nonlinguistic signs. The term "non-verbal communication" includes miscellaneous opportunities of expression, which are neither linguistic nor verbal (Allhoff \& Allhoff, 2014). The listener or conversation partner receives non-verbal signals - although mostly unwittingly - and is significantly influenced by these signals in his/her communication behaviour and subsequent attitude towards the speaker (Allhoff \& Allhoff, 2014). As a result, it can be concluded that "personal impression" is a decisive factor in personal sales. This conclusion is supported by Ambady et al.'s (1993, 2006) 
results, which highlight the relevance of the first impression in sales.

Non-verbal communication fulfils various functions. It supports verbal expression, for instance, hand movements that underline something or rising the voice during important announcements. It can also weaken or strengthen verbal expressions, or even replace them (shaking the head instead of saying "no"). Furthermore, non-verbal communication can contradict verbal expression: thus, sympathy/antipathy, interest/disinterest or honesty/dishonesty can become apparent through non-verbal signs such as body posture, voice timbre, gaze behaviour or facial expression. Another function of non-verbal communication is expressing the opinion of the communication partner. By his/her behaviour, the listener or partner expresses comprehension, incomprehension (nodding or brow raising) or an evaluation (averting his/her gaze, leaning back, folding his/her arms, shrugging). Furthermore, non-verbal communication can express the emotional state and the subjective condition of the communication partner. Examples include socalled body-oriented movements such as rubbing hands or the chin, through which insecurity, thoughtfulness, inner absence, engagement and much more are shown (Allhoff \& Allhoff, 2014). For instance, people in a standing position tend to adopt an attitude with crossed arms if both people dislike each other, compared to if they were fond of each other. Moreover, people with entirely crossed or halfcrossed arms are judged as being dishonest, cold, rejecting, rigid or shy, insecure and passive (Allhoff \& Allhoff, 2014). When a person leans back, this leads to the perception of being rejected, for both men and women. Allhoff and Allhoff (2014) have identified several types of non-verbal expressions. These are mainly visible, but also audible, expressions. Regarding body language, the following main elements are identified:

1. Body posture and body movement

2. Gestures

3. Facial expression

4. Eye contact

For a vocal expression, the following elements are identified:

1. Voice and voice timbre

2. Pronunciation and dialect

\section{Emphasis}

According to Allhoff and Allhoff (2014), other significant ways of communication include:

1. A person's attitude towards the topic

2. His/her mood

3. His/her relationship to the conversation partner

Mehrabian's (1972) study revealed that faceto-face communication is essentially conducted via three channels: body language at 55\% (nonverbal), tone of voice at $38 \%$, words at $7 \%$ (both verbal). The percentages give an indication of the importance of each element. As can been seen, the verbal content of sales talk is of relevance as well. Petty et al. (2004) concluded that central cues involve the logical dissemination of information via the spoken word, while peripheral cues influence attitudes via non-cognitive means, such as body language and gestures. In conclusion, it can be said that "spoken word" and "personal impression" are relevant factors for a successful sales pitch.

Regarding sales styles, the scientific literature distinguishes between "soft-selling" and "hardselling" approaches (Springer Fachmedien Wiesbaden, 2013). The "soft-selling" approach, also known as customer-oriented selling, takes the customer's needs into account. The main intention is to build a long-term relation with the customer by ensuring his/her satisfaction (Springer Fachmedien Wiesbaden, 2013). In contrast, "hard-selling" does not focus on customer satisfaction. Rather, this approach aims to sell the product or service as fast as possible. During the sales process, the buyer's needs are not considered. This sales approach does not aim to gain customer loyalty and/or build a customer relationship. Nevertheless, a new style of hard-selling, which not only aims for a fast sale, but also for long-lasting customer loyalty, has been established in recent years (Springer Fachmedien Wiesbaden, 2013).

Beyond these selling techniques, various questioning techniques can be differentiated as follow: (1) "expedient" questions, (2) "scrutinizing" technique, (3) "converting" technique, (4) "immunizing" and (5) "alternative" questions (Kiwus, 2016, p.137). The questioning technique for "expedient" questions is applied when the salesperson does not want to lose unnecessarily time. Thus, clear questions with the objective of receiving clear answers are asked. In this way, the salesperson 
will soon know which interests the customer is pursuing (Kiwus, 2016). By employing the technique of "scrutinized" questions, the salesperson gains valuable time to give an appropriate answer. In many cases, the customer's questions are answered too quickly and often incorrectly. As a result, false and unnecessary information is forwarded to the customer, for example, the delivery time. In this case, it would be better to ask the customer about the preferred delivery time. This should result in a discussion that avoids false or irrelevant information (Kiwus, 2016). Another strategy is the "converting" technique, which transforms the customer's concerns into questions. As a result, the tension in the situation is allayed as the customer has the possibility to view the case from a different perspective (Kiwus, 2016). The technique of "immunization" seeks to deal with the customer's excuses. Customers are often reluctant to sign up for loyalty cards, giving a lack of time as an excuse. By immunizing, the salesperson directly addresses these excuses and offers the customer different options. For example, the salesperson can suggest that the customer takes the loyalty card application form home, where s/he can read and to fil it out calmly (Kiwus, 2016). Finally, the technique of "alternative" questions is applied for the acquisition of new customers. If the customer is under time pressure and wants to end the conversation, the salesperson should try to arrange an alternative appointment for the sales talk. When asking about the customer's availability, it is useful to initially enquire about general information. For example, the salesperson should ask for the appropriate time of day first, not propose an explicit date. Otherwise, the customer might feel pressed and not agree to another appointment (Kiwus, 2016). The car dealer business can, in the context of sales strategies, be viewed as an illustrative example. Seven sales tactics among car salespeople have been identified by Dratch (2018):

1. Playing out the clock. Some car salespeople draw out the sales process until the buyer becomes tired and hungry, "which weakens you," Crotch says.

2. Psychological profiling. Car salespeople might use psychological profiling to accelerate the sales process by asking scripted questions, which will guide the sales talk in a favourable direction.

3. The pressure of the 'impending event'. The application of pressure on the buyer to decide right now by pretending that circumstances will change, or the product will shortly become unavailable.

4. The 'porcupine close'. With this strategy, the seller "sticks" to the potential buyer a question such as: "If I could get you this monthly payment, would that be what it takes to get you to buy this car today?" All selling is about getting them to buy today. If a person walks out of the dealership, they are not going to buy today.

5. The 'Ben Franklin close'. The salesman draws a line down the middle of a piece of paper, listing reasons to buy the car on one side and reasons not to buy on the other side. The salesperson suggests good reasons to buy and lets the buyer figure out the "don't buy" reasons. This could result in an uncomfortable silence, which says that the buyer cannot think of a reason not to buy the car.

6. The 'alternate choice close'. A choice of two things is offered, such as: "Would you prefer that model in blue or red?" Good car salespeople never ask yes-orno questions because they do not want to give consumers a chance to say "no".

7. The trip to the back office. The finance manager is one of the most skilled people at the dealership. The approach takes shape this way: "Well, you're spending a lot of money on the car. You'd better get tyre protection."

In conclusion, it can be said that, despite the fact that the customer remains an unpredictable factor, the sales talk can be directed by the salesperson and the customer can be partially manipulated by various sales styles (Kiwus, 2016). Soft- and hard-selling approaches can be applied by employing various questioning techniques. In addition, there are different sales strategies that can be applied. There is a lack of scholarly research in the field of sales, considering that most of the sales concepts and guidelines are based on practical experience rather than scientific evidence. Consequently, the aim of the survey is to investigate factors influencing sales behaviour. This research also 
intends to determine the differences between the sales styles and the salesperson's behaviour.

\section{METHODOLOGY}

A quasi-experimental design was chosen for the present study (Koch, 2012). The set-up was based on Ambady's (2006) survey. The object used was a motor car sales situation in a car dealership. Two different salespeople (male and female), during a sales interaction with a mock customer (hardly visible to the observer), were videotaped. The salespeople were asked to conduct the sales pitch according to a given script (verbal and non-verbal content).

Four two-minute videos were produced. Each video featured a "salesperson" talking to a "customer". The videos were filmed so that the viewer could see the upper body of the salesperson but not the customer's facial expressions. In each video, the independent variables ("spoken word", "personal impression" and "authentic impression"), as the "verbal" and "non-verbal" components, were differently manipulated. In relation to the spoken word (verbal), both positive and negative versions of the sales dialogue were scripted (see Appendix A) and acted. The sales script was based on the AIDA formula. The aim was to apply a "softselling" approach by facilitating "defensive" customer involvement to produce a sellerdriven (-influenced) sales script. Furthermore, "expedient", "scrutinizing", "converting", "immunizing" and "alternative" questions were included. The sales strategy of psychological profiling was used. For personal impression (non-verbal), we asked for emphasis of either high or low levels of pleasure, arousal and dominance. In total, four short videos with an "actor-customer" and with two female salespeople were recruited for this experiment. In turn, four different videos with the properties shown in Table 1 were produced. Each video had an original length of about two minutes.

Table 1: Video characteristics

\begin{tabular}{|l|l|l|}
\hline & $\begin{array}{c}\text { Salesperson A } \\
\text { (male) }\end{array}$ & $\begin{array}{c}\text { Salesperson B } \\
\text { (female) }\end{array}$ \\
\hline $\begin{array}{l}\text { Script } \\
\text { (positive) }\end{array}$ & Video 1 (A+) & Video 2(B+) \\
\hline $\begin{array}{l}\text { Script } \\
\text { (negative) }\end{array}$ & Video 3(A-) & Video 4(B-) \\
\hline
\end{tabular}

Each of these short videos contains three main sequences:

- The first sequence represents the "opening" part

- The second sequence shows the sales pitch with the product presentation ("reasoning")

- The third sequence includes the final phase of the sales call ("completion")

For this study, a slightly adapted questionnaire from Ambady (2006) was used. The main question categories were "spoken word", "personal impression" and "authentic impression". The spoken word variable was divided into four items (content, organization, style, tone), which were then divided into a total of six sub-items. The personal impression variable was categorized according to three items (pleasure, arousal, dominance), which were divided into 12 sub-items. The authentic impression variable was categorized according to four items (authentic living, accepting external influence, self-authentication, selfalienation) - for this specific scale, see also Wood (2008) and Barret-Lennard (1998). For the judgements, the questionnaire used a Likert scale (Likert, 1993) from 1 to 7 (1 - strongly disagree, 7 - fully agree). This questionnaire contained a total of 26 questions.

This survey was carried out at a Swiss applied science university over a period of 5 weeks, from the end of July 2017 to the end of August 2017. In total, 154 people participated, all of whom were students. It should be stated here that the students were viable participants: they are potential automotive customers and will, at some point, find themselves in a similar sales situation and making a purchase decision that will be influenced by the salesperson. Every participant received general instructions before taking part in the survey. Before watching the videos, they were handed an instruction sheet with general information about what the survey was about, how long it would take and what they were being asked to do. To ensure the opinions were as unbiased as possible, the study participants were not previously informed as to the purpose and set-up of this study. Only the product was presented and sales material handed out before the start. After reading the instructions, the participants were handed a questionnaire, then given time to read it and look up unknown words. Only then was the first video played. After the video has been played 
entirely, the questionnaire was completed by the participants and collected afterwards.

\section{DATA EVALUATION, FACTOR ANALYSIS THEORY}

Factor analysis is one of the more widely used procedures found in the market researcher's arsenal of analytic tools. Despite its wide-scale usage, factor analysis is not a universally popular technique and has been the subject of much criticism (Ehrenberg, 1968; Ehrenberg \& Goodhart, 1976). Factor analysis is a multivariate statistical technique, which is concerned with the identification of structure within a set of observed variables (Stewart, 1981). As Stewart stated, its appropriate use includes the study of interrelationships among variables in an effort to discover a new set of variables (latent factors), with a smaller number of variables, which highlight the commonality among the original variables. The main aim of factor analysis is to find dimensions within the data and thus it serves as a data reduction technique. There is one general issue that can be resolved with the help of factor analysis: the number of variables can be minimized while the amount of information in the analysis is maximized. In other words, the original data set can be reduced to a smaller data set, while retaining much of the variation in the original data set. There are two types of factor analysis: exploratory (EFA) and confirmatory factor analysis (CFA) (Jöreskog, 1969). In broad terms, EFA is heuristic; it involves the orderly simplification of interrelated measures and has traditionally been used to explore the possible underlying factor structures of a set of observed variables without imposing a preconceived structure on the outcome (Child, 1990). In EFA, the researcher has no expectations regarding the number or nature of the variables (Pett, 2003; Henson, 2006; Thompson \& Daniel, 1996; Swisher, 2004). Conversely, researchers use CFA to test a proposed theory or model. CFA is a form of structural equation modelling, which utilizes a priori assumptions and expectations regarding the number of factors and the factor theories or models that will provide the best fit. The current study used EFA to accomplish the following:

1. Determine the number of factors underlying a set of items (variables)

2. Provide a means of explaining variation among items (variables) using only a few newly created latent variables/factors (e.g., condensing information)

3. Define the content or meaning of the variables/factors

According to Meloun and Melitky (2006), the process of EFA includes the following five steps:

1. Descriptive statistics are used to help ensure that variables have been correctly selected. Both the position and dispersion of the data are reviewed (averages, standard deviation and communality). Communality is an important characteristic showing how well the variable under consideration is predicted by the selected factors.

2. The correlation matrix is calculated in order to assess the total correlation of the data. Bartlett's sphericity test is used to assess whether factor analysis can be utilized; if the total correlation is more than 0.30 , factor analysis can be utilized.

3. To select the proper number of factors using eigenvalues or cumulative percentages.

4. The factor weights are calculated for each factor.

5. The factor scores are used to determine each factor and describe the results.

\section{ANALYSIS AND RESULTS}

The original Switzerland data set includes 154 points (after the deletion of missing dates) and 26 variables. The distribution normality of the data set and subsequently correlation matrix of the data were analysed. To conclude the analysis, data obtained from the survey and video coding were merged and standardized for analysis using MATLAB. The quality of the collected data was assessed in terms of outliers, missing values, skewness and kurtosis. All tested values were within the acceptable range, according to Bortz and Doering (2006). Based on this review, 12 variables were excluded from the factor analysis. Due to the small size of the data set, gender breakdown was not performed. The variable ratio for the current study's data was 1:14. The Kaiser-Meyer-Olkin measure of sampling adequacy (Kaiser, 1970, 1974) is suggested in cases where the variable ratio is less than 1:5. In the current study (with a ratio of 1:14), only Bartlett's (1950) test for sphericity was required. Bartlett's test is used to test the 
null hypothesis: the correlation matrix is an identity, while the counted significance level is less than 0.05 . The latter test proved significant and factor analysis is therefore appropriate for the studied data sets (see Table 2).

Table 2: Results of the test for sphericity

\begin{tabular}{|l|l|l|}
\hline Bartlett's test for & App. chi- & 1003.001 \\
sphericity & square & 1152 \\
Switzerland & Df Sig. & 0.000 \\
\hline
\end{tabular}

The purpose of data extraction is to condense a large number of items into a set of factors. When determining these factors, the simultaneous use of multiple decision rules is recommended (Thompson \& Daniel, 1996). Hair et al. (1995) confirmed this point by highlighting that the majority of factor analysts use several criteria. Typical criteria include Kaiser's criteria (eigenvalue greater than 1 ), the scree test (Cattell, 1966), and the cumulative percentage of variance extracted (Horn, 1965) (see Table 3).

Table 3: Eigenvalues for the data set (Switzerland)

\begin{tabular}{|l|l|l|}
\hline Index & Eigenvalues & $\begin{array}{l}\text { Cumulative } \\
\text { percentage }\end{array}$ \\
\hline 1 & 2.114564 & 40.11 \\
\hline 2 & 1.102568 & 74.00 \\
\hline 3 & 1.000511 & 88.25 \\
\hline 4 & 0.809901 & 100.00 \\
\hline
\end{tabular}

Based on the above decision rules, the authors concluded that the data set should be analysed for three factors, since the eigenvalues in this case are greater than 1 for three factors (see Table 4).

Table 4: Factor loadings - correlations between factors and variables for the data set (Switzerland)

\begin{tabular}{|r|r|r|l|}
\hline Latent Factor 1 & Latent Factor 2 & Latent Factor 3 & Variables \\
\hline 0.8814 & -0.1002 & -0.0398 & Happy \\
\hline 0.8701 & -0.0425 & -0.0474 & Pleased \\
\hline 0.8001 & -0.0987 & 0.1041 & Frenzied \\
\hline 0.7415 & -0.1400 & 0.1100 & Satisfied \\
\hline 0.6300 & -0.0982 & 0.1025 & Contented \\
\hline-0.1223 & 0.8452 & -0.0504 & $\begin{array}{l}\text { The speaker's points flow logically from } \\
\text { one to the next }\end{array}$ \\
\hline 0.1098 & 0.8141 & -0.0444 & $\begin{array}{l}\text { The content and style of the speech does } \\
\text { refer to what is spoken }\end{array}$ \\
\hline-0.0974 & 0.8011 & -0.0447 & The speaker is convincing \\
\hline 0.0907 & 0.6018 & -0.0231 & $\begin{array}{l}\text { The content and style of the speech does } \\
\text { refer to what is spoken }\end{array}$ \\
\hline-0.0584 & -0.0635 & 0.7040 & S/he feels alienated from him/herself \\
\hline 0.1585 & -0.0741 & 0.6999 & S/he is not influenced by others \\
\hline-0.0245 & 0.1574 & 0.6325 & $\begin{array}{l}\text { S/he communicates according to his/her } \\
\text { values and beliefs }\end{array}$ \\
\hline 0.1025 & -0.0421 & 0.6105 & S/he is giving his/her own opinion \\
\hline-0.1788 & -0.0201 & 0.6008 & S/he is true to him/herself \\
\hline & & & \\
\hline & & & \\
\hline
\end{tabular}

As can be seen in Table 3, the first factor is most affected by the variable "happy" (0.8814), followed by the variable "pleased" (0.8701), then by the variables "frenzied" (0.8001) and 
"satisfied" (0.7415), and finally by the variable "contented" (0.6300). The second factor is most affected by the following variables (in order of importance): "The speaker's points flow logically from one to the next"; "The content and style of the speech does refer to what is spoken"; "The speaker is convincing"; "The content and style of the speech does refer to what is spoken". Meanwhile, the last factor is most affected by the following variables: "S/he feels alienated from him/herself"; "S/he is not influenced by others"; "S/he communicates according to his/her values and beliefs"; "S/he is giving his/her own opinion"; "S/he is true to him/herself".

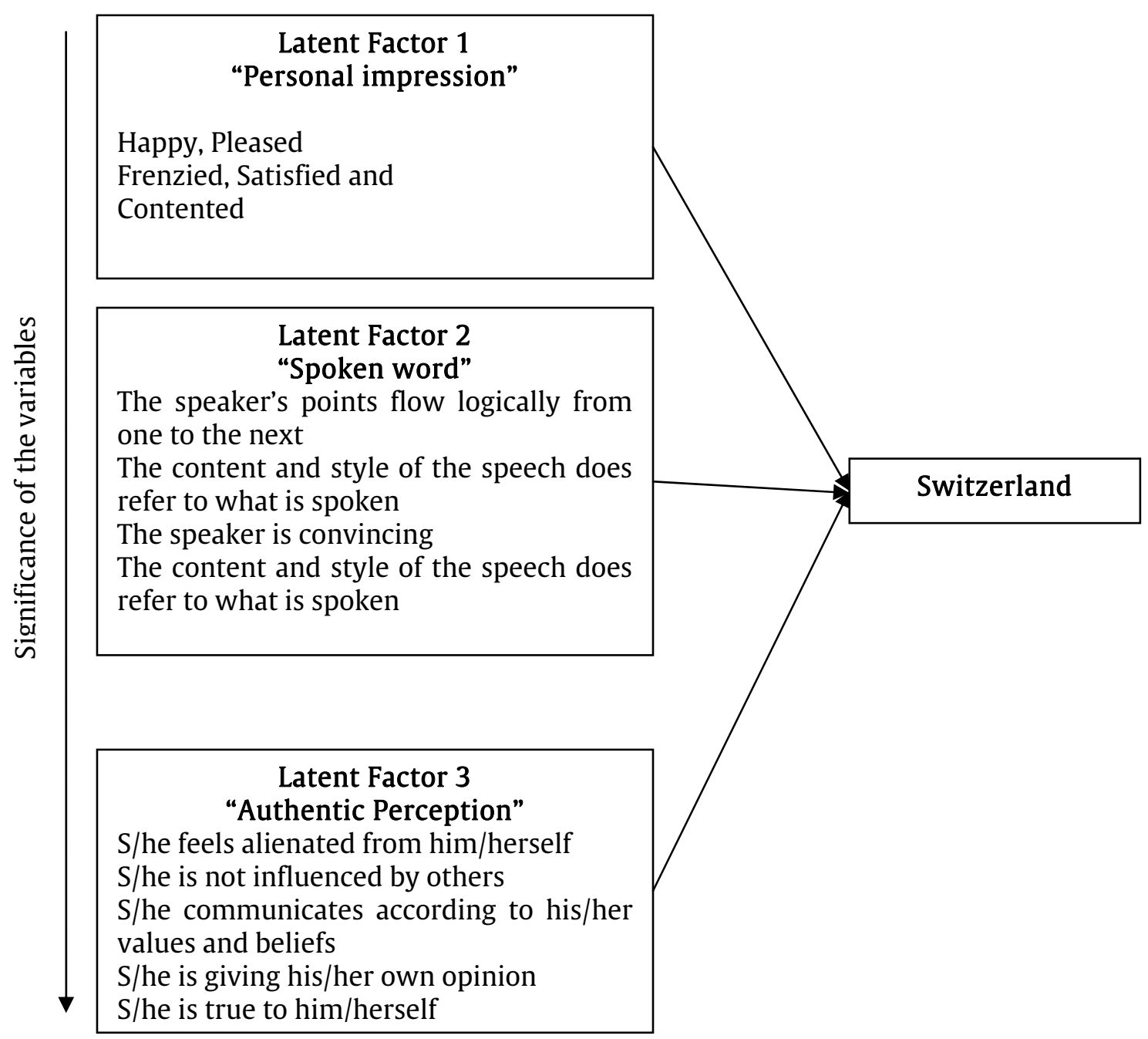

Figure 1: Personal sales model

The purpose of the rotation step is to simplify the factor structure of a group of items (Costello, 2005). Rotation maximizes high-item loadings and minimizes low-item loadings, thus producing a simplified solution that is easier to interpret. There are two rotation techniques: orthogonal (varimax/quartimax) and oblique (olbimin/promax) rotation. Orthogonal varimax rotation, first developed by Thompson (2004), is the most common rotational technique and produces factor structures that are uncorrelated.
Oblique rotation produces correlated factors. Results are often considered more accurate for research involving human behaviours, or when data do not meet a priori assumptions (Costello, 2005). Regardless of which rotation method is used, the primary objective is to provide parsimonious solutions that are easy to interpret (Kieffer, 1999). Factor loadings and rotations were used to calculate the factor scores, and the variables included within each factor were then determined. Next, the 
correlations between the obtained factors were calculated and the results indicated insignificant correlations between obtained factors. The factor results are shown in Figure 1.

\section{DISCUSSION AND CONCLUSION}

This study has revealed some interesting findings on the relevant factors for a successful salesperson in a wealthy market environment. Based on this, some theoretical and practical conclusions can be drawn. For the non-verbal variable (personal impression), the sub-item of pleasure appeared to be the most relevant criterion. This means that personal appearance (such as smiling), friendliness and personal empathy are regarded as the most relevant factors. As a result, a salesperson needs to emphasize these personal attributes.

At this point it should be stated that besides the investigated Swiss automotive market, other markets also demand high-quality customer service and high quality products, such as the Japanese automotive market. According to Kaynak and Herbig (2013), "door-to-door selling is popular in Japan. As many as half of the cars sold in Japan are sold by door-to-door salesmen. Toyota Motor Corporation alone has more than 100,000 door-to-door salespeople."

For the verbal component of sales (spoken word), it could be identified that the organization, content and style of speech are the most relevant items. In practical terms, this means that clearly structured sales talk is of importance, such as by following the AIDA formula. Consequently, every sales talk should be carefully prepared beforehand. This controlled procedure can increase the salesperson's authenticity and persuasive power.

Besides these two criteria ("personal impression" and "spoken word"), the literature clearly states that an authentic impression is of relevance to sales success (Bauer, 2005). This study has identified that the criteria of "not feeling alienated by him/herself", "not being influenced by others", "communicating according to his/her beliefs and values" are the main factors for an authentic impression. Despite the fact that authenticity is portrayed by the personality of the sales representative, it can also be influenced by training programmes. In general, it can be said that soft-selling approaches are preferred and offensive customer involvement should be targeted. It also needs to be emphasized that sales talk should be guided by the salesperson. This can be done by applying different sales strategies and questioning techniques.

As a result, this study offers several practical applications. First, today's marketing and sales managers must understand the importance of salesperson authenticity. Perceptions of authenticity are largely dependent on nonverbal communication. This immediately raises the practical question: Can a salesperson be trained to systematically make a better impression? Feiertag (2004, p10) suggested that a "learning program to improve the first impression should be a self-imposed part of a person's training." Therefore, sales training programs are encouraged to include impression management techniques. The emotional regulation required for personal impression management may be generated by surface acting or deep acting (Grandey, 2003; Reyers \& Matusitz, 2012). Surface acting focuses on changing external behaviors, while deep acting focuses on modifying inner feelings in the hope that modification will consequently lead to the ideal authentic state (Halpern \& Luba, 2003; Henning-Thurau et al., 2006). Research indicates that impression management via surface acting often spawns emotional exhaustion and should not be encouraged as a long-term impression management technique (Reyers \& Matusitz, 2012). Thus, deep acting methodologies are preferable, and further research is required to determine approaches by which to teach deep method acting in sales training scenarios.

Furthermore, at a time when consumer behaviour is characterized by various factors, such as information retrieval from the Internet, influencing needs through social contacts and networks, bonding with customers is greatly challenging. An important criterion for creating a unique feature for a company is hiring and employing qualified salespeople. This is a major cost factor in business management.

\section{LIMITATIONS AND FUTURE RESEARCH}

In summary, it can be stated that a more uniform selection of subjects with consideration of their gender and age would have been more appropriate. This would have allowed for a more regular distribution of age and gender and made the sample more representative. The survey period does not reflect the number of subjects. The sample is too small for this. For 
further empirical studies, a larger sample should be produced. Second, the location of the study poses a potential limitation. The fact that the experiment was conducted using an automotive dealership from the United States raises the question about whether the findings can be generalized to other business markets and varying cultural environments (see also Říha, Heinze \& Stros, 2017; Stros, Říha \& MösleinTröppner, 2018; Stros, Heinze \& Říha, 2017). Another possible limitation could relate to the fact that university students were used as participants rather than existing customers. However, considering that the students are potential automotive customers, we do not view this limitation as significant.

Regarding future research, there is a need to study the influence of other marketing factors in relation to the derived model. In particular, marketing activities related to product, pricing, distribution and promotional activities should be assessed in terms of the AIDA concept (see also Lewis, 1903). Additionally, a comparison with other markets or regions might also be valuable. In a sales situation, the customer will assess the salesperson and the salesperson will assess the customer. This immediately points to venues for further research. to evaluate if an salespeople can be trained to secure better sales by improving their psychological profiling skills and enabling them to assess the customer's willingness to buy quickly? Not losing too much time with the wrong prospect is a mantra in business-to-business sales situations.

\section{ACKNOWLEDGMENT}

We would like to thank Adalbert Jung, Fernfachhochschule Schweiz, Brig, for the valuable support.

\section{REFERENCES}

Allhoff, D.-W. and Allhoff, W. (2014). Rhetorik \& Kommunikation - ein Lehr- und Übungsbuch, 16. Auflage, Ernst Reinhardt Verlag, Munich.

Ambady, N. and Rosenthal, R. (1993). Half a minute: predicting teacher evaluations from thin slices of nonverbal behaviour and physical attractiveness, Journal of Personality and Social Psychology, 64, 3 , 431-441.

Ambady, N., Krabbenhoft, M. and Hogan, D. (2006). The 30-sec sale: using thin-slice judgments to evaluate sales effectiveness, Journal of Consumer Psychology, 16, 1, 4-13.

Barrett-Lennard, G.T. (1998). Carl Rogers' Helping System: Journey and Substance, Sage, London.

Bartlett, M.S. (1950). Tests of significance in factor analysis, British Journal of Psychology, 3 (Part II), 77-85.

Bauer, J. (2005). Warum ich fühle, was du fühlst: intuitive Kommunikation und das Geheimnis der Spiegelneurone, Hoffmann und Campe, Hamburg.

Bortz, J. and Doering, N. (2006). Forschungsmethoden und Evaluation, 4, Springer, Heidelberg.

Cattell, R.B. (1966). The scree test for the number of factors, Multivariate Behavioural Research, 1, 2, 245-276.

Child, D. (1990). The Essentials of Factor Analysis, Second Edition, Cassel Educational Limited, London.

Churchill, G., Ford, N., Hartley, S. and Walker, O. (1985). The determinants of salesperson performance, a meta-analysis, Journal of Marketing Research, 22, May, 103-118.

Costello, A.B. and Osborne, J.W. (2005). Best practices in exploratory factor analysis: four recommendations for getting the most from your analysis, Practical Assessment, Research and Evaluation, 10, 7, 1-9.

Dratch, D. (2018). 7 tactics car salesmen hope you don't know, Bankrate, London, February (www.bankrate.com/loans/auto-loans/7secret-tactics-that-car-salesmen-hope-youdont-know/).

Ehrenberg, A.S.C. (1968). On methods: the factor analytic search for program types, Journal of Advertising Research, 8, March, 55-63.

Ehrenberg, A.S.C. and Goodhart, G.J. (1976). Factor Analysis: Limitations and Alternatives, Marketing Science Institute Working Paper, No. 76-116, Marketing Science Institute, Cambridge, MA.

Feiertag, H. (2004). You Never Get a Second Chance to Make a First Impression, Hotel \& Motel Management, 219, 19, p10.

Fischer, G.H. (1982). Interaktionsstrategie im Absatzmarketing - Grundlagen und Anwendungen, Deutscher BetriebswirteVerlag, Gernsbach. 
Foscht T., Swoboda B. and Schramm-Klein H. (2015). Käuferverhalten, 5. Auflage, Springer Verlag, Berlin.

Freud, S. (1938). Abriss der Psychoanalyse. Fischer, Frankfurt.

Grandey, A.A. (2003). When 'the Show Must Go On': Surface Acting and Deep Acting as Determinants of Emotional Exhaustion and Peer-rated Service Delivery, Academy of Management Journal, 46, 1, 86-96.

Hair J., Anderson, R.E., Tatham, R.L. and Black, W.C. (1995). Multivariate Data Analysis, Fourth Edition, Prentice-Hall Inc., Upper Saddle River, NJ.

Halpern, B.L. and Luba, K. (2003). Leadership Presence: Dramatic Techniques to Reach Out, Motivate, and Inspire, Gotham Book NY.

Hennig-Thurau T, Groth M. et al. (2006). Are All Smiles Created Equal? How Emotional Contagion and Emotional Labour Affect Service Relationships, Journal of Marketing, 70, 58-73.

Henson, R.K. and Roberts, J.K. (2006). Use of exploratory factor analysis in published research: common errors and some comment on improved practice, Educational and Psychological Measurement, 66, 393416.

Homburg, C., Schäfer, H. and Schneider, J. (2012). Sales Excellence - Systematic Sales Management, Springer, Berlin.

Horn, J.L. (1965). A rationale and test for the number of factors in factor analysis, Psychometrika, 30, 2, 179-85.

Jöreskog, K.G. (1969). A general approach to confirmatory maximum likelihood factor analysis, Psychometrika, 23, 187-200.

Kaiser, H.F. (1970). A second-generation little jiffy, Psychometrika, 35, 4, 401-15.

Kaiser, H.F. and Mark, I.V. (1974). Little jiffy, Educational and Psychological Measurement, 34, 111-117, 20.

Kaynak, E. and Herbig, P. (2013) Cross-Cultural Makering, Cross-Cultural Issues in Sales and Sales Management, Routledge Member of the Taylor and Francis Group, Cogent OA.

Kieffer, K.M. (1999). An introductory primer on the appropriate use of exploratory and confirmatory factor analysis, Research in Schools, 6, 2, 75-92.
Kirchgeorg, M. and Wübbenhorst, K. (2013). Marktforschung, Springer Gabler Verlag, Wiesbaden.

Kiwus D. (2016). Mehr Verkaufserfolg durch Selbstcoaching, 5. Auflage, Springer Gabler Verlag, Wiesbaden.

Kromney, H. (2006). Empirische Sozialforschung, 11. Auflage, UTB Verlag, Stuttgart.

Kruglanski, A.W. and Van Lange, P.A.M. (2012). Handbook of Theories of Social Psychology, Sage, London, 224-245.

Kuß, A., Wildner, R. and Kreis, H. (2014). Marktforschung Grundlagen der Datenerhebung und Datenanalyse, 5. Auflage, Springer Gabler Verlag, Wiesbaden.

Mehrabian, A. (1972). Nonverbal Communication, Aldine-Atherton, Chicago IL.

Meloun, M. and Militký, J. (2006). Kompendium statistického zpracování dat: metody a řešené úlohy, Academia, Prague.

Pett, M., Lackey, N. and Sullivan, J. (2003). Making Sense of Factor Analysis, Sage Publications, Inc., Thousand Oaks CA.

Petty, R. (1986). Communication and Persuasion: Central and Peripheral Routes to Attitude Change, Springer-Verlag, New York.

Petty, R.E., Rucker, D.D., Blizer, G.Y. and Cacioppo, J.T. (2004). The elaboration likelihood model of persuasion. In Seiter, J.S. and Gass, R.H. (eds.), Perspectives on Persuasion, Social Influence, and Compliance Gaining, 65-89, Pearson, Boston MA.

Pufahl, M. (2015). Sales Performance Management - Exzellenz im Vertrieb mit ganzheitlichen Steuerungskonzepten, Springer Gabler, Düsseldorf.

Reyers A. and Matusitz J. (2012). Emotional Regulation at Walt Disney World: An Impression Management View, Journal of Workplace Behavioral Health, 27, 3,139159.

Říha, D., Heinze, T. and Stros, M. (2017). Intercultural Variations in Personal Sales Factors in the Czech and U.S. Automotive Markets: Practical Implications for Marketing, Central European Business Review, 6, 1, March, 26-47. 
Schuckel, M. (1999). Bedienungsqualität im Einzelhandel, Kohlhammer Verlag, Stuttgart.

Solomon, M.R., Bamossy, G. and Askegaard, S. (2003). Konsumentenverhalten - Der europäische Markt, Pearson Verlag, Frankfurt am Main.

Springer Fachmedien Wiesbaden (2013). Wirtschaftslexikon Gabler; Auflage 18, Verlag Springer Gabler, Wiesbaden.

St. Elmo Lewis, E. (1903). Catch-line and argument, The Book-Keeper, 15, February, 124.

Stewart, D.W. (1981). The application and misapplication of factor analysis in marketing research, Journal of Marketing Research, 18, 1, February, 51-62.

Stewart, David W. (1981). The application and misapplication of factor analysis in marketing research, Journal of Marketing Research, 18, 1, 51-62.

Stewart, E.C. and Bennett, M.J. (1991). American Cultural Patterns: A Cross-cultural Perspective, Intercultural Press, Yarmouth, ME.

Stros, M., Heinze, T. and Říha, D. (2017). Relevance of Personal Interaction Factors between Customers and Sales Representatives in the Automotive Business, Journal of Applied Marketing Theory, 7, 1, April, 33-55.

Stros, Michael; Říha, David and MösleinTröppner, Bodo (2018). The Role of Gender in Salesperson Perception, Marketing Sciences \& Inspirations, Vol. XIII, No. 3, Pages 11-23.

Swisher, L.L., Beckstead, J.W. and Bebeau, M.J. (2004). Factor analysis as a tool for survey analysis using a professional role orientation inventory as an example, Physical Therapy, 84, 9, 784-799.

Thompson B. and Daniel, L.G. (1996). Factor analytic evidence for the construct validity of scores: a historical overview and some guidelines, Educational and Psychological Measurement, 56, 2, 197-208.

Wage, J.L. (1991). Psychologie und Technik des Verkaufsgesprächs, 11. Auflage, Verlag moderne Industrie, Landsberg am Lech.

Weber, S. (2017). Consumers' preferences in the Swiss car market, IRENE Working Paper 1612, September, Institute of Economic Research, University of Neuchatel.
Weinberg, P. (1986). Nonverbale Marktkommunikation, Physica-Verlag, Heidelberg.

Weis, H.C. (1994). Verkaufsgesprächsführung, 2. überarbeitete und erweiterte Auflage, Neue Wirtschafts-Briefe Verlag, Ludwigshafen.

Wood, A.M., Linley, P.A., Maltby, J., Baliousis, M. and Joseph, S. (2008). The authentic personality: a theoretical and empirical conceptualization and the development of the authenticity scale, Journal of Counselling Psychology, 55, 3, 385-399. 


\section{Appendix A}

Car Sales Script - Positive Example

Introduction (Attention, Expedient Question)

S: Good afternoon, my name is Steven Johnson of Imperial Autos. How may I help you or should I leave you alone?

C: Thanks, I'm just looking around right now.

$\mathrm{S}$ : Is there anything you're particularly looking for?

C: Well, yes, I want a car with better gas mileage.

Value Statement (Attention, Expedient Question)

S: Great, if you don't mind can I ask you a few more questions, and then I'll recommend a few vehicles that might be a good fit for you. My intention is to help you determine if there is a vehicle on our lot that will better meet your needs than your current car.

C: OK, that sounds fine.

\section{Disqualify Statement (Attention, Scrutinizing Question)}

S: Wonderful. Since I'm not certain if we have a car that is right for you, let me ask a couple of questions?

C. Sure.

\section{Qualifying Questions (Interest, Converting Questions)}

S: How satisfied are you with your vehicle at the current time?

C: Somewhat dissatisfied.

S: What are you currently driving?

C: A Honda Accord.

S: How old is your Accord? Did you purchase it brand new or what was the mileage when you first brought it?

C: About eight years old.

S: If you could change anything about your Accord, what would you change?

C: Better gas mileage. I'd like to get at least 40 miles to the gallon.
Common Pain Points (Interest, Converting Questions)

$\mathrm{S}$ : Besides the gas mileage, are there any other features or functional or quality concerns that you have with your Accord. For example, some customers want a bigger car, a better safety rating or a new style.

C. Not really, I'm pretty satisfied with my car. I just want to get better gas mileage.

\section{Building Interest Points (Desire, Immunizing Question)}

S: Oh, ok. I understand. So, tell me about the type of gas mileage you would like. You said you would like an average of 40 miles per gallon?

C: Yes, that's right. I want to average around 40, between the highway and the city.

S: Well, then, I might recommend the Ford Fusion Hybrid. It averages around $40 \mathrm{mpg}$, and it handles very nicely as well.

C: Yes, but I did some research on the Internet, and the Fusion Hybrid is more expensive than the Honda Accord.

S: You are right. It is more expensive. But are you more concerned about upfront expense, or long-term operating costs?

C: So, you think the gas savings of the Fusion Hybrid will more than compensate for the higher cost?

S: Yes, you are right.

\section{Close (Action, Alternative Question)}

S: Would you like to walk into the dealership with me, and we can discuss some specific numbers?

C: OK, yes, let's do that.

S: Great. Here at Imperial Autos, we have a nohaggle sales approach, so you can be assured that we will offer you a straightforward price that will be very competitive. Let's go and figure out how we can make this work for you. 


\section{ABOUT THE AUTHORS}

Michael Stros, email: michael.stros@ffhs.ch

Dr. Michael Stros is the Head of the Marketing Group and teaches at the University of Applied Sciences and Arts of Southern Switzerland (SUPSI), Fernfachhochschule Schweiz, Brig, Switzerland. His main research interests focus on Pharmaceutical Marketing and Personal Sales. Besides of his academic activities, Michael is a Marketing Consultant and Sales Trainer. In his previous professional activities, Michael was engaged as a Product and Sales Manager for International Biotech Companies.

Dr. David Ǩíha is a is an Assistant Professor at the Department of Marketing of the Faculty of Business Administration at the University of Economics, Prague and from 2013 also at the University of Applied Sciences Upper Austria School of Management / Steyr. Education at the University of Economics, College of Business and Management Faculty of Escuela Superior de Marketing y Administración Barcelona supported within the study internships in Finland, Mexico, Austria and the UK. His practical experience is in sales and marketing gained on managerial positions in national and international companies and through consulting activities.

Dr. Elena Říhová is an assistant of professor at Skoda Auto University. She received the Ph.D. degree from the University of Economics in Prague, Czech Republic, in 2016. She is currently with the Czech Technical University and Skoda Auto University. Her main research is focused on Fuzzy Clustering and Factor Analysis. Her research interests also include others multivariate statistical methods.

Dr. Lynn L.K. Lim is a Professor of Global Consumer Research and the Programme Head for the Master of Science (MSc) in International Management at the School of Business, University of Applied Sciences and Arts Northwestern Switzerland (FHNW). 